\title{
US national bioethics commission: Politics as usual?
}

\author{
Russ Hoyle
}

"To the extent that bioethics is a field based on principle rather than compromise, politics can only corrupt it." That observation, made by Boston University ethicist George Annas some 18 months ago, may be worth remembering now that the Clinton White House is poised to convene the long-awaited National Bioethics Advisory Commission (NBAC). The NBAC represents the first federal panel for reviewing major ethical questions arising from genetic and other human research since the presidential commission on biomedical research, established by President Jimmy Carter, went out of business more than a decade ago.

The creation of the new national commission is long overdue. Few serious scientists, ethicists, or even biotechnology industry executives dispute the need for a federal bioethics review committee in an age of intensely controversial processes, such as fetal tissue research, xenografts, artificial and transgenic organ transplants, gene patenting, and prospective genetic therapy. "The general view is that it's desirable," says Alexander Morgan Capron, a well-known ethicist and professor of law and medicine at the University of California at Los Angeles.

Even so, there is a palpable sense of skepticism about the new panel stemming from the fact that Washington policy makers are so far behind the curve on bioethics. In Europe, similar commissions are already well established, from Britain's Nuffield Council on Bioethics (London) and UNESCO's International Bioethics Committee (Paris) to the European Commission's Group of Advisers on Ethical Implications of Biotechnology (Brussels). For many in the fast-changing bioethics community, the memory of then-Republican $\mathrm{Al}$ Gore's last venture in bioethics in the mid-1980s, the congressional Biomedical Ethics Advisory Committee, is still uncomfortably fresh.

The deliberations of that bipartisan committee were hobbled at the outset by former President George Bush's moratorium on fetal research. Virtually from the outset, the panel, made up of legislators from both the US House of Representatives and the Senate, was deadlocked over the abortion issue. "There's certainly a history of difficulty with bioethics commissions," admits a White House Office of Science and Technology Policy (OSTP; Washington, DC) spokesperson. "We hope that NBAC will function more effectively." After such a long dry spell, it is no wonder that the timing of the White House announcement hailing the creation of the new bioethics commission, less than a month before the Republican Party convention in San Diego, has spurred skepticism about the administration's political aims.

Still, the broad outlines of the new commission's charter and its mission have been well known since it was established in a October 1995 Executive Order by President Clinton. The group is charged with considering the "rights and welfare of human research subjects and issues in the management and use of genetic information, including, but not limited to, human gene patenting." The NBAC was conceived with a distinctly pragmatic purpose: to "provide advice" and "make recommendations" to the federal government through the National Science and Technology Council (Washington, DC) on "programs, policies, assignments, missions, guidelines, and regulations as they relate to bioethical issues." It is also empowered to identify "broad principles to govern the ethical conduct of research," though enjoined from the consideration of specific projects.

The 15-member NBAC board, which will be appointed by the president, will include experts in bioethics and theology, the social sciences, law, medicine, and health care, biological research, and at least three members of the general public. Its meetings, expected to number some 10 per year, will be open to the press and published in the Federal Register. The commission will have wide discretion to establish its own agenda, based on a number of criteria, including public health, "public policy urgency," relevance to federal "science and technology investment goals" and to the "extent of interest in the issue within the federal government."

The scope of the Clinton commission is therefore still somewhat uncertain and has been understandably criticized for its vagueness. The 1994 charter proposed by the OSTP, however, was quite clear about the kind of "discrete issues" that will fall under its purview. These include questions of genetic privacy, screening for genetic disorders, intellectual property rights, access to research data and informed consent, federal human subject research guidelines, probing and defining the idea of "minimal risk," and ethical aspects of access to expensive medical technology.
The panel is in part an outgrowth of efforts by several agencies to form an advisory committee to examine an array of issues raised by the Human Genome Project. The new commission's work is likely to overlap with the agenda of the Human Genome Project's working group on the ethical, legal, and social implications of human genome research (known as ELSI), but the commission will be authorized to incorporate ELSI's work, or the work of other advisory bodies, when warranted.

The commission will have the authority to subcontract analyses, reports, and other background materials and gather material from other federal agencies for its consideration. NBAC will be staffed and supported by the US Department of Health and Human Services, though it will be overseen jointly by OSTP.

If a new presidential bioethics commission is to be successful, argued Boston University's George Annas in the winter edition of the Hastings Center Report two years ago, it must meet several conditions. First, it must move beyond narrow questions of law into broader considerations of morality. "The major challenge contemporary bioethics faces is to move its focus beyond defining the minimum morality the law requires and more into the realm of the right and the good."

Such a standing body, of course, always has the potential to rubber-stamp and provide political cover for difficult questions already decided by policy makers. This, says Annas, is precisely how politics corrupts ethics. To avoid such pitfalls, Annas writes, an effective bioethics commission must take as its mission the review of difficult, or "'big time' research in public before it is done." He notes wryly that such bodies "usually have been called on late and treated like a second-class citizen."

If bioethics is to make its mark in the real world of politics and industry, the Clinton commission will have to learn the politics of medicine and genetic research, both in the private and public sectors. The trick for an effective bioethics panel, says Annas, is "to influence politics and policy without corrupting itself by making it seem that ethical principles and practice are the result of compromise and majority vote. .."

That is a tall order. But at the outset at least, the new NBAC appears to have the right stuff to get the job done. The rest will depend on the commission's leadership, its members, and the political will of the current occupants of the White House. /II 